\section{Journal of}

Gastroenterology
GE Port J Gastroenterol 2023;30:166-168

DOI: $10.1159 / 000520907$
Received: September 14, 2021

Accepted: October 26, 2021

Published online: December 10, 2021

\title{
An Unusual Endoscopic Finding of Gastric Crohn's Disease
}

\author{
Isabel Garrido ${ }^{a, b}$ João Santos-Antunes ${ }^{a, b} \quad$ Guilherme Macedo ${ }^{a, b}$ \\ ${ }^{a}$ Gastroenterology and Hepatology Department, Centro Hospitalar Universitário de São João, Porto, Portugal; \\ ${ }^{b}$ World Gastroenterology Organization (WGO) Porto Training Center, Porto, Portugal
}

\section{Keywords}

Crohn's disease $\cdot$ Stomach $\cdot$ Bariatric surgery

\section{Doença de Crohn gástrica - um achado endoscópico pouco comum}

\section{Palavras Chave}

Doença de Crohn · Estômago · Cirurgia bariátrica

A 37-year-old woman with a past medical history of obesity (body mass index $50 \mathrm{~kg} / \mathrm{m}^{2}$ ) and Crohn's disease (Montreal classification - A2 L2+L4 B1) was referred to our institution for bariatric surgery after several unsuccessful weight loss attempts. The diagnosis of Crohn's disease was established at age 19 (Fig. 1) and at that time she started therapy with azathioprine and a prednisolone taper. Due to poor control of the disease, the patient underwent several long courses of corticosteroid therapy. At this point, she began to gradually increase her weight. Over the past 4 years, the patient has been on infliximab at $5 \mathrm{mg} / \mathrm{kg}$ every 8 weeks, with evidence of clinical and endoscopic remission.

karger@karger.com www.karger.com/pjg

Karger" (c) 2021 Sociedade Portuguesa de Gastrenterologia. Published by S. Karger AG, Basel

This is an Open Access article licensed under the Creative Common Attribution-NonCommercial-4.0 International License (CC BY-NC) (http://www.karger.com/Services/OpenAccessLicense), applicable to the online version of the article only. Usage and distribution for commercial purposes requires written permission.
A preoperative esophagogastroduodenoscopy was requested in order to assess the upper gastrointestinal tract for any abnormal findings as well as the presence of Helicobacter pylori (HP) infection. The endoscopy revealed retracted scar tissue in the gastric body (Fig. 2a) and antrum (Fig. 2b), with lesions with a bamboo-joint-like appearance and several pseudopolyps (Fig. 3). The esophagus and duodenum appeared normal. Histopathologic examination of biopsies from the stomach demonstrated mild foveolar hyperplasia and HP-negative chronic gastritis, with no signs of activity. No epithelioid granulomas, glandular atrophy, dysplasia, or signs of malignancy were identified.

The patient underwent a sleeve gastrectomy without complications. The surgical specimen did not reveal any specific sign for inactive Crohn's disease. Indeed, histopathological evaluation of the surgical specimen showed chronic gastritis and hyperplasia of the foveolar epithelium cells, without active inflammation, granulomas, dysplasia, or signs of malignancy. Five months after the surgery, she has already lost $36 \mathrm{~kg}$ and Crohn's disease remains in remission.

Crohn's disease is defined by chronic inflammation that may involve any site of the gastrointestinal tract.

Correspondence to:

Isabel Garrido, isabelmng@hotmail.com 

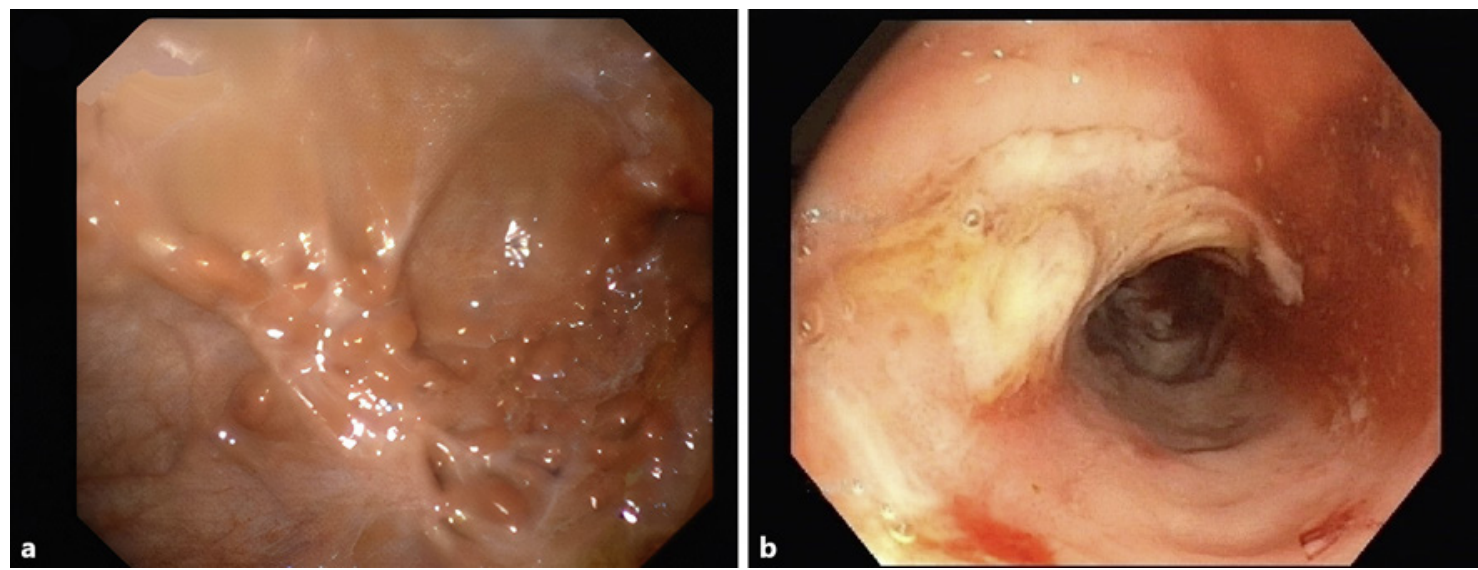

Fig. 1. Endoscopic exams at diagnosis. a Esophagogastroduodenoscopy - stomach with scattered scarring areas and multiple pseudopolyps. b Colonoscopy - congestive and friable colonic mucosa, with scattered erosions and ulcers, interspersed with normal-looking mucosa.
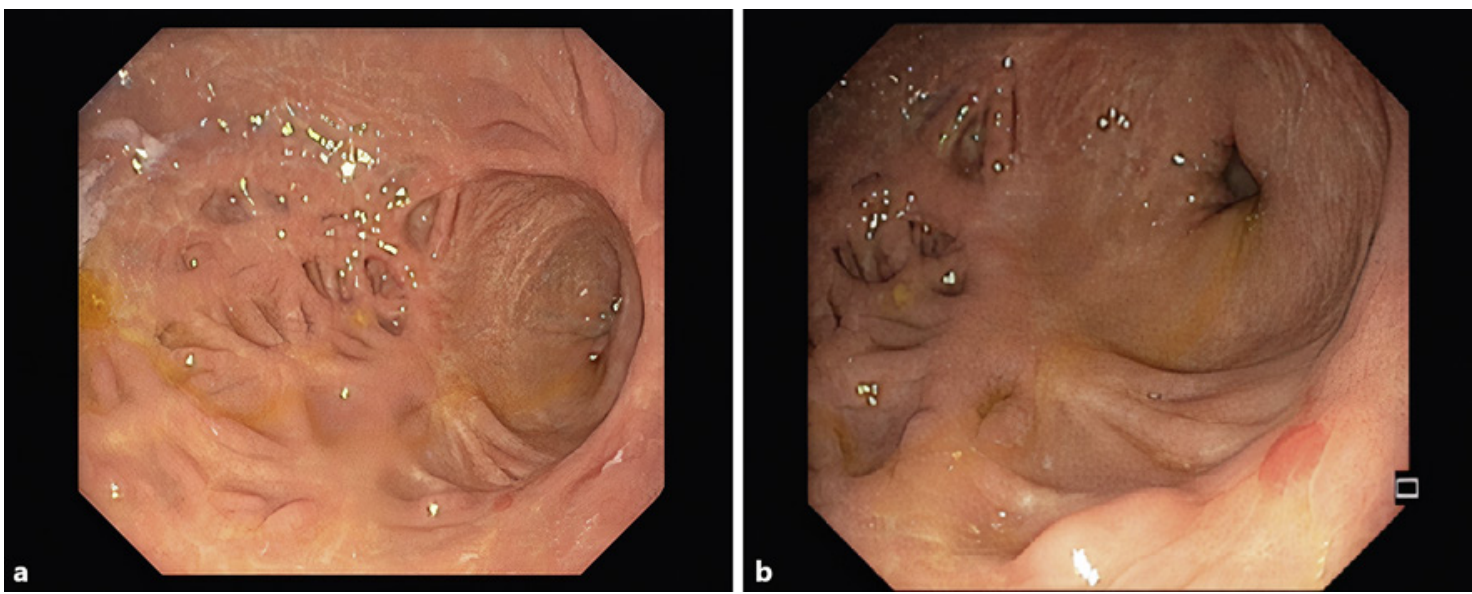

Fig. 2. Gastric body (a) and antrum (b) involvement by Crohn's disease.

Nevertheless, the stomach is rarely the sole or predominant site of Crohn's disease accounting for less than $0.07 \%$ of all cases of gastrointestinal Crohn's disease $[1,2]$. We report a rare case of gastric Crohn's disease with endoscopic findings consistent with cicatricial mucosa, remarkable for its exuberance. Furthermore, it has been shown that bariatric surgery may be an effective and safe option for weight loss in carefully selected patients with inflammatory bowel disease [3].

\section{Statement of Ethics}

Informed consent was obtained from the patient for the publication of their information and imaging.

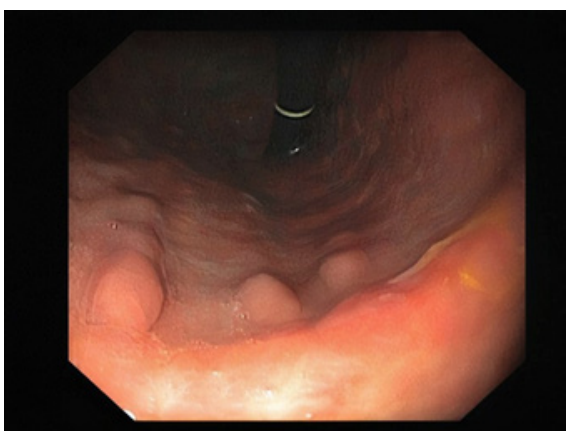

Fig. 3. Bamboo-joint-like appearance and pseudopolyps on the stomach. 


\section{Conflict of Interest Statement}

The authors have no disclosures to report.

\section{Funding Sources}

Not applicable.

\section{Author Contributions}

Isabel Garrido drafted the manuscript. Isabel Garrido, João Santos-Antunes, and Guilherme Macedo have critically revised and finalized the manuscript. All authors have approved the final version of the manuscript.
1 Laube R, Liu K, Schifter M, Yang JL, Suen MK, Leong RW. Oral and upper gastrointestinal Crohn's disease. J Gastroenterol Hepatol. 2018 Feb;33(2):355-64.

2 Horjus Talabur Horje CS, Meijer J, Rovers L, van Lochem EG, Groenen MJ, Wahab PJ. Prevalence of Upper Gastrointestinal Lesions at Primary Diagnosis in Adults with Inflammatory Bowel Disease. Inflamm Bowel Dis. 2016 Aug;22(8):1896-901.

3 Hudson JL, Barnes EL, Herfarth HH, Isaacs KL, Jain A. Bariatric Surgery Is a Safe and Effective Option for Patients with Inflammatory Bowel Diseases: A Case Series and Systematic Review of the Literature. Inflamm Intest Dis. 2019 Apr;3(4):173-9. 